\title{
Ion atmosphere relaxation controlled electron transfers in cobaltocenium polyether molten salts
}

Amanda S. Harper-Leatherman

Fairfield University, aharper@fairfield.edu

Anthony M. Leone

Dongil Lee

Wei Wang

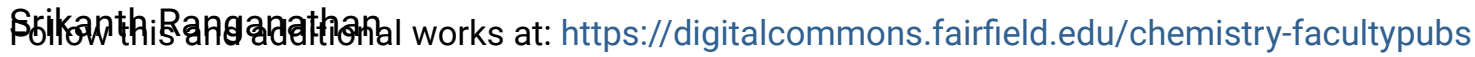

Copyright 2005 American Chemical Society

She puxlishequarticle is alsa available on the journal site:

http://pubs.acs.org/doi/abs/10.1021/jp051380j

\section{Peer Reviewed}

\section{Repository Citation}

Harper-Leatherman, Amanda S.; Leone, Anthony M.; Lee, Dongil; Wang, Wei; Ranganathan, Srikanth; Williams, Mary E.; and Murray, Royce W., "Ion atmosphere relaxation controlled electron transfers in cobaltocenium polyether molten salts" (2005). Chemistry \& Biochemistry Faculty Publications. 5. https://digitalcommons.fairfield.edu/chemistry-facultypubs/5

\section{Published Citation}

Harper, Amanda S.; Leone, Anthony M.; Lee, Dongil; Wang, Wei; Ranganathan, Srikanth; Williams, Mary E.; Murray, Royce W. "Ion atmosphere relaxation controlled electron transfers in cobaltocenium polyether molten salts." Journal of Physical Chemistry B, 2005, 109 (40), 18852-18859.

This item has been accepted for inclusion in DigitalCommons@Fairfield by an authorized administrator of DigitalCommons@Fairfield. It is brought to you by DigitalCommons@Fairfield with permission from the rightsholder(s) and is protected by copyright and/or related rights. You are free to use this item in any way that is permitted by the copyright and related rights legislation that applies to your use. For other uses, you need to obtain permission from the rights-holder(s) directly, unless additional rights are indicated by a Creative Commons license in the record and/or on the work itself. For more information, please contact digitalcommons@fairfield.edu. 


\section{Authors}

Amanda S. Harper-Leatherman, Anthony M. Leone, Dongil Lee, Wei Wang, Srikanth Ranganathan, Mary E. Williams, and Royce W. Murray 


\title{
Ion Atmosphere Relaxation Controlled Electron Transfers in Cobaltocenium Polyether Molten Salts
}

\author{
Amanda S. Harper, ${ }^{\dagger}$ Anthony M. Leone, ${ }^{\ddagger}$ Dongil Lee, ${ }^{\S}$ Wei Wang, Srikanth Ranganathan," \\ Mary Elizabeth Williams, ${ }^{\perp}$ and Royce W. Murray* \\ Kenan Laboratories of Chemistry, University of North Carolina, Chapel Hill, North Carolina 27599-3290
}

Received: March 16, 2005

\begin{abstract}
A room-temperature redox molten salt for the study of electron transfers in semisolid media, based on combining bis(cyclopentadienyl)cobalt with oligomeric polyether counterions, $\left[\mathrm{Cp}_{2} \mathrm{Co}\right]\left(\mathrm{MePEG}_{350} \mathrm{SO}_{3}\right)$, is reported. The transport properties of the new molten salt can be varied (plasticized) by varying the polyether content. The charge transport rate during voltammetric reduction of the ionically conductive $\left[\mathrm{Cp}_{2} \mathrm{Co}\right]\left(\mathrm{MePEG}_{350} \mathrm{SO}_{3}\right)$ molten salt exceeds the actual physical diffusivity of $\left[\mathrm{Cp}_{2} \mathrm{Co}\right]^{+}$because of rapid $\left[\mathrm{Cp}_{2} \mathrm{Co}\right]^{+/ 0}$ electron self-exchanges. The measured $\left[\mathrm{Cp}_{2} \mathrm{Co}\right]^{+/ 0}$ electron self-exchange rate constants $\left(k_{\mathrm{EX}}\right)$ are proportional to the diffusion coefficients $\left(D_{\text {CION }}\right)$ of the counterions in the melt. The electron-transfer activation barrier energies are also close to those of ionic diffusion but are larger than those derived from optical intervalent charge-transfer results. Additionally, the $\left[\mathrm{Cp}_{2} \mathrm{Co}\right]^{+/ 0}$ rate constant results are close to those of dissimilar redox moieties in molten salts where

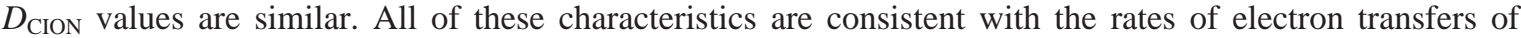
$\left[\mathrm{Cp}_{2} \mathrm{Co}\right]^{+/ 0}$ (and the other donor-acceptor pairs) being controlled not by the intrinsic electron-transfer rates but by the rate of relaxation of the ion atmosphere around the reacting pair. In the low driving force regime of mixed-valent concentration gradients, the ion atmosphere relaxation is competitive with electron transfer. The results support the generality of the recently proposed model of ionic atmosphere relaxation control of electron transfers in ionically conductive, semisolid materials.
\end{abstract}

\section{Introduction}

This paper describes the results of a continuing investigation using model redox semisolids to probe the microscopic effects of semirigid environments on electron-transfer dynamics and physical mass transport rates. The model semisolids are combinations of polyether oligomers with (normally crystalline) redox-active compounds, that produce highly viscous, amorphous, room-temperature, ionically conductive molten salts. ${ }^{1}$ The mass transport and electron-transfer properties of these molten salts (e.g., ionic liquids) can be manipulated by varying the polyether chain, ${ }^{2}$ chain length, ${ }^{1 \mathrm{c}}$ electrolyte, ${ }^{1 \mathrm{~d}}$ and redox species ${ }^{\mathrm{lh}, 3}$ and by adding small molecules that "plasticize" the melt. ${ }^{4}$ In general, the homogeneous electron self-exchange reactions in the semirigid melts, in the mixed-valent layers formed around electrodes, exhibit small rate constants $\left(k_{\mathrm{EX}}\right)$ and have large thermal activation energy barriers $\left(E_{\mathrm{A}, \mathrm{EX}}\right)$ relative to those for analogous reactions in dilute, fluid solutions, ${ }^{1 \mathrm{~b}-\mathrm{d}}$ or to those predicted from classical Marcus theory for an ether-like dielectric environment. ${ }^{5}$ Additionally, the thermal barrier energies are approximately 2-fold larger than those derived from optically induced electron-transfer results ${ }^{3 c, d, 7 a}$ based on Hush theory. ${ }^{6}$

Our early analysis ${ }^{1 \mathrm{a}, \mathrm{e}}$ of the slow electron-transfer dynamics observed in semisolid redox molten salts was based on a solvent dynamics model. This model has been reconsidered recently, 4,7 since it appears that a more accurate interpretation can be based

* Corresponding author. E-mail: rwm@email.unc.edu

$\dagger$ Present address: Naval Research Laboratory, Washington, DC.

$\doteqdot$ Present address: Merck \& Co., Inc., West Point, PA.

$\S$ Present address: Western Michigan University, Kalamazoo, MI.

" Present address: Nanosys, Inc., Palo Alto, CA.

${ }^{\perp}$ Present address: Pennsylvania State University, University Park, PA. on the dynamics of the ion atmosphere surrounding the donoracceptor reaction pair. Specifically, electron transfer is followed by a Coulombically driven redistribution of neighboring ions that, in low free energy gradients characteristic of mixed-valent concentration gradients, competes with the back electron-transfer reaction. Slow ion relaxation allows a high incidence of back electron transfers and overall rate control by the diffusion rates of the ions. The rates and energy barriers for electron transfer thus reflect not the intrinsic electron-transfer barrier but instead the thermal barrier for counterion transport. The new analysis has been supported by results in tris-bipyridine ${ }^{4 a, b}$ and trisphenanthroline ${ }^{4 \mathrm{~b}, \mathrm{c}}$ cobalt molten salts, where (a) a 1:1 proportionality is found between the counterion diffusion coefficient $\left(D_{\mathrm{CION}}\right)$ and both heterogeneous $\mathrm{Co}(\mathrm{III} / \mathrm{II})$ and homogeneous $\mathrm{Co}(\mathrm{II} / \mathrm{I})$ electron-transfer rates, (b) the electron-transfer barrier energies are close to those of ion diffusion, and (c) electron transfer becomes silent ${ }^{4 \mathrm{~d}}$ when the counterion is immobile (e.g., DNA). The consistency of the results obtained by varying the fluidity of the melts through polyether chain length differences, temperature, electrolyte addition, or addition of unattached polyether and $\mathrm{CO}_{2}$ plasticizers adds strength to the analysis. ${ }^{4}$ In addition, the rates of homogeneous electron transfers in two ruthenium-complex-based melts are $^{7}$ in accord with the ion atmosphere relaxation model.

It is important to study semisolid melt redox materials that differ from the Co and Ru poly-pyridine complexes, ${ }^{4,7}$ in order to assess how generally applicable the ion atmosphere model is. The cobaltocenium complex was chosen for this study because, as compared to poly-pyridine Co complexes, it is smaller $^{8}$ and more diffusive and it is only singly charged. This report describes mass transport and $\left[\mathrm{Cp}_{2} \mathrm{Co}\right]^{+/ 0}$ electron-transfer dynamics in molten salts (Figure 1) in which the cobaltocenium 

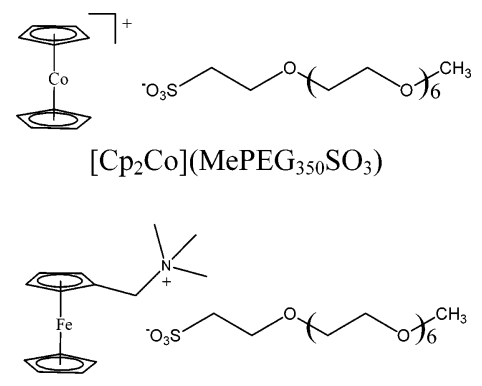

[FcTMA] $\left(\mathrm{MePEG}_{350} \mathrm{SO}_{3}\right)$

Figure 1. Structure of the cobaltocenium counterion-tailed melt, $\left[\mathrm{Cp}_{2}\right.$ $\mathrm{Co}]\left(\mathrm{MePEG}_{350} \mathrm{SO}_{3}\right)$, and the ferrocenylmethyltrimethylammonium counterion-tailed melt, [FcTMA](MePEG $\left.{ }_{350} \mathrm{SO}_{3}\right)$.

species is provided with a sulfonate counterion to which a $\mathrm{MePEG}_{350}$ oligomer (methyl-terminated poly(ethylene glycol), average MW 350) is covalently bonded, that is, $\left(\mathrm{MePEG}_{350} \mathrm{SO}_{3}{ }^{-}\right.$). The fluidity of the $\left[\mathrm{Cp}_{2} \mathrm{Co}\right]\left(\mathrm{MePEG}_{350} \mathrm{SO}_{3}\right)$ molten salt can be manipulated by adding unattached, neutral $\mathrm{MePEG}_{350}$ oligomer as a plasticizer. Electron-transfer and mass transport measurements were made in the neat and MePEG-plasticized $\left[\mathrm{Cp}_{2} \mathrm{Co}\right]^{+}$ melt as a function of temperature. In addition, a structurally similar melt, ferrocenylmethyltrimethylammonium having a MePEG-tailed counterion ([FcTMA $]^{+}\left(\mathrm{MePEG}_{350} \mathrm{SO}_{3}{ }^{-}\right.$) (Figure $1)$ ), was mixed with the $\left[\mathrm{Cp}_{2} \mathrm{Co}\right]\left(\mathrm{MePEG}_{350} \mathrm{SO}_{3}\right)$ melt to prepare a $1: 1 \mathrm{~mol} / \mathrm{mol}[\mathrm{FcTMA}]\left(\mathrm{MePEG}_{350} \mathrm{SO}_{3}\right) /\left[\mathrm{Cp}_{2} \mathrm{Co}\right]\left(\mathrm{MePEG}_{350^{-}}\right.$ $\mathrm{SO}_{3}$ ) melt. Charge transport and optically induced $\mathrm{Co}(\mathrm{III} / \mathrm{II})$ electron transfer were studied in the [FcTMA] $\left(\mathrm{MePEG}_{350} \mathrm{SO}_{3}\right) /$ $\left[\mathrm{Cp}_{2} \mathrm{Co}\right]\left(\mathrm{MePEG}_{350} \mathrm{SO}_{3}\right)$ mixed melt.

The results of the above melt measurements include rate constants for homogeneous $\mathrm{Co}$ (III/II) electron self-exchanges $\left(k_{\mathrm{EX}}\right)$

$$
\left[\mathrm{Cp}_{2} \mathrm{Co}\right]^{+}+\left[\mathrm{Cp}_{2} \mathrm{Co}\right]^{0} \rightarrow\left[\mathrm{Cp}_{2} \mathrm{Co}\right]^{0}+\left[\mathrm{Cp}_{2} \mathrm{Co}\right]^{+}
$$

and self-diffusion coefficients of the Co complexes ( $\left.D_{\mathrm{PHYS}}\right)$ and the MePEG-tailed counterions $\left(D_{\mathrm{CION}}\right)$ in the $\left[\mathrm{Cp}_{2} \mathrm{Co}\right]\left(\mathrm{MePEG}_{350^{-}}\right.$ $\mathrm{SO}_{3}$ ) melt. The $\mathrm{Co}(\mathrm{III} / \mathrm{II})$ electron self-exchange rates were measured voltammetrically from the enhanced apparent diffusivity $\left(D_{\mathrm{APP}}\right)$ observed upon reducing the $\mathrm{Co}(\mathrm{III})$ complex, that is attributed to electron hopping within the $\mathrm{Co}(\mathrm{III} / \mathrm{II})$ mixedvalent diffusion layer generated around the electrode. The electron hopping or "electron diffusion" $\left(D_{\mathrm{E}}\right)$ contribution to $D_{\text {APP }}$ is estimated using the cubic lattice model $^{9}$

$$
D_{\mathrm{APP}}=D_{\mathrm{PHYS}}+D_{\mathrm{E}}=D_{\mathrm{PHYS}}+k_{\mathrm{EX}} \delta^{2} C / 6
$$

where $\delta$ is the equilibrium center-to-center distance between complexes ${ }^{10}$ and $C$ is the total concentration of cobalt complex sites in the melt.

$D_{\text {PHYS }}$ was measured by diluting $\left[\mathrm{Cp}_{2} \mathrm{Co}\right]\left(\mathrm{MePEG}_{350} \mathrm{SO}_{3}\right)$ to 10 mol \% with the structurally similar melt [FcTMA](MePEG $350^{-}$ $\mathrm{SO}_{3}$ ). This mole percentage is below the percolation threshold for electron hopping in semisolid melts, ${ }^{11}$ so that the voltammetric currents are controlled solely by physical diffusion of the reactant, $\left[\mathrm{Cp}_{2} \mathrm{Co}\right]^{+}$. The counterion diffusion rate $\left(D_{\mathrm{CION}}\right)$ was calculated from the melt ionic conductivity using the Nernst-Einstein relation, an approach recently validated by direct voltammetry of iodide as a model counterion. ${ }^{4 \mathrm{c}, 7 \mathrm{~b}}$

The temperature dependence of $k_{\mathrm{EX}}$ is used to determine the activation energy barriers for thermally induced electron transfer in the cobaltocenium melts. These barrier energies are compared to those for ionic conductivity and physical diffusion, and to a barrier energy calculated from an observed optically induced electron-transfer absorbance band, based on Hush theory. ${ }^{6}$

The results for the cobaltocenium melt show a 1:1 proportionality between the $\mathrm{Co}(\mathrm{III} / \mathrm{II})$ electron-transfer and ionic diffusion rates. In comparison, a less exact $1: 1$ correlation is found between the electron-transfer rate and physical diffusion of $\left[\mathrm{Cp}_{2} \mathrm{Co}\right]^{+}$(a groundwork of the earlier solvent dynamics interpretation $\left.^{1 \mathrm{a}, \mathrm{e}}\right)$. These new results add general support for the ion atmosphere relaxation model of electron transfer in ionically conductive, semirigid environments.

\section{Experimental Section}

Synthesis of $\left(\mathrm{MePEG}_{350} \mathrm{SO}_{3}{ }^{-}\right)\left(\mathrm{Na}^{+}\right)$. This sulfonated poly(ethylene glycol) oligomer was prepared by a published procedure. $^{4 \mathrm{c}}$

Synthesis of $\left(\mathrm{MePEG}_{350} \mathbf{S O}_{3}{ }^{-}\right)\left(\mathrm{Bu}_{4} \mathbf{N}^{+}\right)$. In a column, $\sim 75$ g of Dowex 50WX2-400 strongly acidic cation exchange resin (Aldrich) ( $0.33 \mathrm{~mol}$ equiv of exchange groups) was treated with $\sim 1 \mathrm{~L}$ of $5 \mathrm{M}$ hydrochloric acid, followed by $1 \mathrm{~L}$ of Nanopure water. The column was converted to the $\mathrm{Bu}_{4} \mathrm{~N}^{+}$form with a $\mathrm{Bu}_{4} \mathrm{NOH}$ solution and then thoroughly washed with $1 \mathrm{~L}$ of distilled water, $500 \mathrm{~mL}$ of methanol, and $1 \mathrm{~L}$ of Nanopure water. (Thorough washing is essential to remove amines and other contaminants.) A solution containing $\sim 5 \mathrm{mmol}$ of $\left(\mathrm{MePEG}_{350^{-}}\right.$ $\left.\mathrm{SO}_{3}{ }^{-}\right)\left(\mathrm{Na}^{+}\right)$was passed into this column and the $\left(\mathrm{MePEG}_{350^{-}}\right.$ $\left.\mathrm{SO}_{3}{ }^{-}\right)\left(\mathrm{Bu}_{4} \mathrm{~N}^{+}\right)$product eluted with an excess of $200 \mathrm{~mL}$ of water. Complete exchange of $\mathrm{Bu}_{4} \mathrm{~N}^{+}$for $\mathrm{Na}^{+}$was confirmed by NMR; 28 aliphatic H's are seen in the $\delta=1.0-1.7 \mathrm{ppm}$ range relative to 28 polymer protons around $\delta=3.6 \mathrm{ppm} . \delta=$ $1.0 \mathrm{ppm}$ (t $12 \mathrm{H}$ 's), $\delta=1.45 \mathrm{ppm}$ (m $8 \mathrm{H}$ 's),$\delta=1.65 \mathrm{ppm}(\mathrm{m}$ $8 \mathrm{H}$ 's), $\delta=2.6 \mathrm{ppm}$ (s 4H's, impurity eliminated by 100 MWCO dialysis), $\delta=3.11 \mathrm{ppm}$ (t 2 H's), $\delta=3.25 \mathrm{ppm}$ (t 8 H's), $\delta=3.35$ ppm (s 3 H's), $\delta=3.63$ ppm (m 25 H's), $\delta=$ 3.9 ppm (t 2 H's).

Synthesis of the Molten Salt $\left[\mathrm{Cp}_{2} \mathrm{Co}^{+}\right]\left(\mathrm{MePEG}_{350} \mathrm{SO}_{3}{ }^{-}\right)$. Aqueous cobaltocenium hexafluorophosphate (Strem, 98\%) and $\left(\mathrm{MePEG}_{350} \mathrm{SO}_{3}{ }^{-}\right)\left(\mathrm{Bu}_{4} \mathrm{~N}^{+}\right)$solutions (in 1:1 mol/mol proportions) were mixed, the resulting $\mathrm{Bu}_{4} \mathrm{NPF}_{6}$ precipitate was filtered, and the solution was dried in a vacuum. NMR in $\mathrm{CDCl}_{3}$ showed complete counterion metathesis: 10 aromatic H's (singlet $\delta=$ $6.5 \mathrm{ppm}$ ) relative to 31 polymer H's (m $\delta=3-4 \mathrm{ppm}$ ). Additional purification by dialysis in a $100 \mathrm{MWCO}$ bag for 48 $\mathrm{h}$ removed excess cobaltocenium, $\mathrm{NH}_{4}{ }^{+}$, and $\mathrm{MePEG}_{350} \mathrm{SO}_{3}{ }^{-}$. Anal. Calcd: C, 48.5; H, 6.6; N, 0; S, 5.2; Co, 9.5; F, 0. Found: C, 50.04; H, 7.32; N, <0.02; S, 4.49; Co, 9.33; F, 0.12.

Synthesis of $\left[\mathrm{FcTMA}^{+}\right]\left(\mathrm{MePEG}_{350} \mathrm{SO}_{3}{ }^{-}\right)$. Following a published procedure, ${ }^{4 \mathrm{~b}}$ an aqueous solution of $\sim 290 \mathrm{mg}$ of $\left(\mathrm{MePEG}_{350} \mathrm{SO}_{3}{ }^{-}\right)\left(\mathrm{Na}^{+}\right)$was passed through $\sim 13 \mathrm{~g}$ Dowex of 50WX2-200 (Aldrich) strongly acidic cation exchange resin pretreated with $1 \mathrm{~L}$ of $4 \mathrm{M}$ hydrochloric acid, producing a solution of $\left(\mathrm{MePEG}_{350} \mathrm{SO}_{3} \mathrm{H}\right)$. An aqueous solution containing $\sim 230 \mathrm{mg}$ of ferrocenylmethyltrimethylammonium iodide (FcTMA ${ }^{+} \mathrm{I}^{-}$, Strem, 99\%) was passed through $\sim 15 \mathrm{~g}$ of Dowex 1X2-400 (Aldrich) strongly basic anion exchange resin that had been pretreated with $1 \mathrm{~L}$ of $4 \mathrm{M}$ sodium hydroxide. The resulting $\mathrm{FcTMA}^{+} \mathrm{OH}^{-}$solution was immediately titrated to neutrality with the $\mathrm{MePEG}_{350} \mathrm{SO}_{3} \mathrm{H}$ solution and the water removed via vacuum evaporation.

Plasticization and Dilution of $\left[\mathrm{Cp}_{2} \mathrm{Co}^{+}\right]\left(\mathrm{MePEG}_{350} \mathrm{SO}_{3}{ }^{-}\right)$. A $5.2 \mathrm{mg}$ portion of $\left[\mathrm{Cp}_{2} \mathrm{Co}^{+}\right]\left(\mathrm{MePEG}_{350} \mathrm{SO}_{3}{ }^{-}\right.$) (dried under vacuum for at least $12 \mathrm{~h}$ ) was added to $4.6 \mathrm{mg}$ of $\mathrm{MePEG}_{350}$ (Aldrich, treated with Celite) dissolved in $\mathrm{CH}_{2} \mathrm{Cl}_{2}$ to make a $1: 1.6 \mathrm{~mol} / \mathrm{mol}\left[\mathrm{Cp}_{2} \mathrm{Co}^{+}\right]\left(\mathrm{MePEG}_{350} \mathrm{SO}_{3}{ }^{-}\right) / \mathrm{MePEG}_{350}$ mixture. The solvent was removed by rotary evaporation. A $75.2 \mathrm{mg}$ 
portion of $\left[\mathrm{FcTMA}^{+}\right]\left(\mathrm{MePEG}_{350} \mathrm{SO}_{3}{ }^{-}\right)$was combined with 71.4 $\mathrm{mg}$ of $\left[\mathrm{Cp}_{2} \mathrm{Co}^{+}\right]\left(\mathrm{MePEG}_{350} \mathrm{SO}_{3}{ }^{-}\right)$in the same manner to produce a molten salt containing a $1: 1$ mole ratio of $\left[\mathrm{Cp}_{2}-\right.$ $\left.\mathrm{Co}^{+}\right]\left(\mathrm{MePEG}_{350} \mathrm{SO}_{3}{ }^{-}\right) /\left[\mathrm{FcTMA}^{+}\right]\left(\mathrm{MePEG}_{350} \mathrm{SO}_{3}{ }^{-}\right)$.

Electrochemical Measurements. Potential step chronoamperometry and cyclic voltammetry of the Co(III/II) electrochemical reaction were conducted on a neat film of the redox polyether hybrid resting on a microelectrode assembly, as before. ${ }^{1}$ See the Supporting Information for further details.

Digital Simulation. Simulation of experimental cyclic voltammetry was done with Digisim 3.03. ${ }^{12}$ A hemispherical microelectrode geometry was used to generate the simulation, taking a hemisphere of the same area as the experimental disk electrode. The concentration was held constant while the diffusion coefficient and uncompensated resistance were varied to fit the peak splitting and peak current of the experimental cyclic voltammograms $(\mathrm{CVs})$ at 25 and $70{ }^{\circ} \mathrm{C}$ at $1 \mathrm{mV} / \mathrm{s}$. Then, the scan rate was changed at each temperature to obtain the other simulations.

Spectroscopic Measurements. Detection of optically induced electron transfers was sought using an optically transparent thin layer cell consisting of face-to-face indium tin oxide (ITO)coated (Delta Technologies) $25 \mathrm{~mm} \times 75 \mathrm{~mm}$ glass slides, separated by $\sim 50 \mu \mathrm{m}$ of MonoKote (TopFlite, Great Plains Model Distributors) and sealed with Torr Seal. The thin layer cavity was filled (before sealing, in a dry, inert atmosphere) with $\sim 1-2 \mathrm{mg}$ of the $1: 1$ mixed $\left[\mathrm{Cp}_{2} \mathrm{Co}^{+}\right]\left(\mathrm{MePEG}_{350} \mathrm{SO}_{3}^{-}\right) /$ $\left[\mathrm{FcTMA}^{+}\right]\left(\mathrm{MePEG}_{350} \mathrm{SO}_{3}{ }^{-}\right)$melt. The currents resulting from applying potential bias to the two ITO electrodes (Pine Instruments RDE4 potentiostat), so as to oxidize and reduce the two redox constituents at opposing electrodes, ${ }^{13}$ were monitored on a Yokogawa $3025 \mathrm{X}-\mathrm{Y}$ recorder, and near-IR (NIR) spectra of the thin layer sample were monitored with a BioRad FTS 6000 spectrometer fitted with a PbSe detector. Microdisk voltammetry of the melt was used to determine the necessary values of the potential bias. The spectrum of the cell before the potential bias was applied (showing a spectral decay from the IR to visible, presumably from the ITO film) was subtracted from subsequent spectra taken under the potential bias.

\section{Results and Discussion}

Mass Transport and Electron-Transfer Rate Measurements. $D_{\mathrm{PHYS}}, D_{\mathrm{APP}}$, and $D_{\mathrm{CION}}$ transport measurements were carried out in three melts: neat $\left[\mathrm{Cp}_{2} \mathrm{Co}\right]\left(\mathrm{MePEG}_{350} \mathrm{SO}_{3}\right)$, a 1.6:1 $\mathrm{mol} / \mathrm{mol} \mathrm{MePEG}_{350}$-plasticized $\left[\mathrm{Cp}_{2} \mathrm{Co}\right]\left(\mathrm{MePEG}_{350} \mathrm{SO}_{3}\right)$ melt,

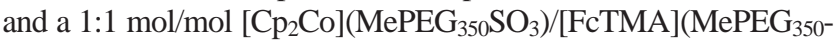
$\mathrm{SO}_{3}$ ) mixed melt.

The microdisk voltammetry currents observed for the $\left[\mathrm{Cp}_{2}-\right.$ $\mathrm{Co}\left(\mathrm{MePEG}_{350} \mathrm{SO}_{3}\right.$ ) (Figure 2A) and $\mathrm{MePEG}_{350}$-plasticized $\left[\mathrm{Cp}_{2} \mathrm{Co}\right]\left(\mathrm{MePEG}_{350} \mathrm{SO}_{3}\right.$ ) (Figure 2B) melts were large (compared to those in cobalt poly-pyridine melts ${ }^{4}$ ) and displayed sigmoidal waveshapes, indicative of radial diffusion conditions resulting from fast charge transport. That the Figure $2 \mathrm{~A} 1 \mathrm{mV} / \mathrm{s}$ $70{ }^{\circ} \mathrm{C}$ voltammogram is unchanged at $3 \mathrm{mV} / \mathrm{s}$ is also consistent with radial diffusion control. The Figure 2 voltammograms are well-fitted by digital simulations ${ }^{12}$ assuming radial diffusion (Supporting Information Figures S-2, S-3, and S-4), except at lower temperatures in the neat melt (Supporting Information Figure $\mathrm{S}-1,25^{\circ} \mathrm{C}$ ), for reasons associated with adsorption or precipitation of $\left[\mathrm{Cp}_{2} \mathrm{Co}\right]^{0}$. Regarding the latter, see the discussion at the end of paper.

Voltammograms of the three melts at $38^{\circ} \mathrm{C}-$ neat, $\mathrm{MePEG}_{350^{-}}$ plasticized, and mixed-are compared in Figure 3. In the
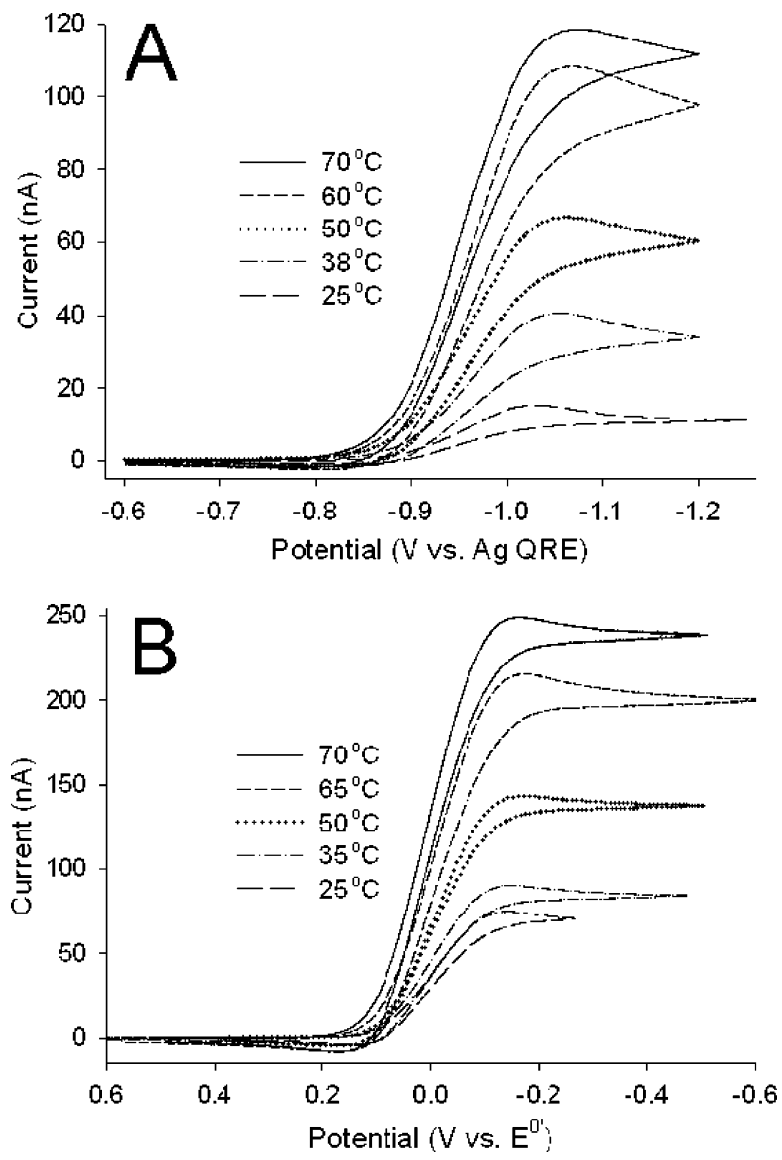

Figure 2. (A) Cyclic voltammetry at indicated temperatures and 1 $\mathrm{mV} / \mathrm{s}$ of the neat $\left[\mathrm{Cp}_{2} \mathrm{Co}\right]\left(\mathrm{MePEG}_{350} \mathrm{SO}_{3}\right)$ melt at a $\mathrm{Pt}$ microdisk electrode with a radius of $12.4 \mu \mathrm{m}$. (B) Cyclic voltammetry at indicated temperatures and $1 \mathrm{mV} / \mathrm{s}$ of the $\mathrm{MePEG}_{350}$-plasticized $\left[\mathrm{Cp}_{2} \mathrm{Co}\right]-$ $\left(\mathrm{MePEG}_{350} \mathrm{SO}_{3}\right.$ ) melt (mole ratio 1.6:1) at a Pt microdisk electrode with a radius of $14.4 \mu \mathrm{m}$. The 65 and $70{ }^{\circ} \mathrm{C}$ data were taken at $2 \mathrm{mV} / \mathrm{s}$.

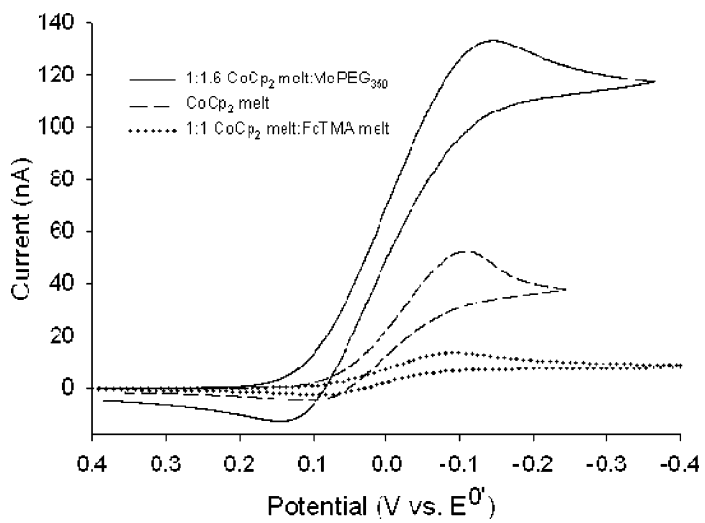

Figure 3. Cyclic voltammetry at $5 \mathrm{mV} / \mathrm{s}$ of the neat $\left[\mathrm{Cp}_{2} \mathrm{Co}\right]-$ $\left(\mathrm{MePEG}_{350} \mathrm{SO}_{3}\right.$ ) melt at $38^{\circ} \mathrm{C}$ (dashed line), the $\mathrm{MePEG}_{350}$-plasticized $\left[\mathrm{Cp}_{2} \mathrm{Co}\right]\left(\mathrm{MePEG}_{350} \mathrm{SO}_{3}\right.$ ) melt (mole ratio 1.6:1) at $40{ }^{\circ} \mathrm{C}$ (solid line), and the mixed $\left[\mathrm{Cp}_{2} \mathrm{Co}\right]\left(\mathrm{MePEG}_{350} \mathrm{SO}_{3}\right) /[\mathrm{FcTMA}]\left(\mathrm{MePEG}_{350} \mathrm{SO}_{3}\right)$ melt (mole ratio $1: 1$ ) at $38^{\circ} \mathrm{C}$ (dotted line). The $k_{\mathrm{EX}}$ results are $1.2 \times 10^{7}$, $7.5 \times 10^{7}$, and $5.0 \times 10^{6} \mathrm{M}^{-1} \mathrm{~s}^{-1}$, based on $D_{\mathrm{PHYS}}$ values of $1.5 \times$ $10^{-9}, 1.6 \times 10^{-8}$, and $1.5 \times 10^{-9} \mathrm{~cm}^{2} / \mathrm{s}$, respectively, for the neat, $\mathrm{MePEG}_{350}$-plasticized, and mixed melts. The $D_{\mathrm{PHYS}}$ values are from chronoamperometry ${ }^{15}$ of the $\mathrm{Co}(\mathrm{III} / \mathrm{II})$ reaction in $10 \mathrm{~mol} \%\left[\mathrm{Cp}_{2} \mathrm{Co}\right]-$ $\left(\mathrm{MePEG}_{350} \mathrm{SO}_{3}\right)$ in [FcTMA] $\left(\mathrm{MePEG}_{350} \mathrm{SO}_{3}\right)$ or plasticized [FcTMA]$\left(\mathrm{MePEG}_{350} \mathrm{SO}_{3}\right)$.

$\mathrm{MePEG}_{350}$-plasticized $\left[\mathrm{Cp}_{2} \mathrm{Co}\right]\left(\mathrm{MePEG}_{350} \mathrm{SO}_{3}\right)$ melt, the Co(III/II) currents are substantially enhanced relative to the neat melt, by the presence of the plasticizer; the larger currents reflect (vide infra) increases in both the $D_{\text {PHYs }}$ value of the $\left[\mathrm{Cp}_{2} \mathrm{Co}\right]^{+}$ 
TABLE 1: Physical Transport and Electron-Transfer Results for $\left[\mathrm{Cp}_{2} \mathrm{Co}\right]\left(\mathrm{MePEG}_{350} \mathrm{SO}_{3}\right)$ Melts (at $\left.25^{\circ} \mathrm{C}\right)\left(\mathrm{Cp}_{2} \mathrm{Co}\right.$, Neat Melt; $\mathrm{Cp}_{2} \mathrm{Co} / \mathrm{FcTMA}, 1: 1 \mathrm{~mol} / \mathrm{mol}$ $\left[\mathrm{Cp}_{2} \mathrm{Co}\right]\left(\mathrm{MePEG}_{350} \mathrm{SO}_{3}\right) /[\mathrm{FcTMA}]\left(\mathrm{MePEG}_{350} \mathrm{SO}_{3}\right)$ Mixed Melt; $\mathrm{Cp}_{2} \mathrm{Co} / \mathrm{MePEG}_{350}, 1.6: 1 \mathrm{~mol} / \mathrm{mol} \mathrm{MePEG}_{350}$-Plasticized $\left.\left[\mathrm{Cp}_{2} \mathrm{Co}\right]\left(\mathrm{MePEG}_{350} \mathrm{SO}_{3}\right)\right)$

\begin{tabular}{|c|c|c|c|}
\hline melt & $\mathrm{Cp}_{2} \mathrm{Co}$ & $\begin{array}{c}1: 1 \mathrm{Cp}_{2} \mathrm{Co} / \\
\text { FcTMA }\end{array}$ & $\begin{array}{c}1: 1.6 \mathrm{Cp}_{2} \mathrm{Co} / \\
\mathrm{MePEG}_{350}\end{array}$ \\
\hline$C^{a}(\mathrm{M})$ & 1.9 & 1.0 & 0.98 \\
\hline & & & \\
\hline$D_{\mathrm{PHYS}}^{c}\left(25^{\circ} \mathrm{C}\right)\left(\mathrm{cm}^{2} / \mathrm{s}\right)$ & $3.9 \times 10^{-10}$ & $3.9 \times 10^{-10}$ & $1.1 \times 10^{-8}$ \\
\hline$D_{\mathrm{CION}}^{d}\left(25^{\circ} \mathrm{C}\right)\left(\mathrm{cm}^{2} / \mathrm{s}\right)$ & $6.3 \times 10^{-9}$ & $3.5 \times 10^{-9}$ & $1.2 \times 10^{-8}$ \\
\hline$D_{\mathrm{I}}^{e}\left(25^{\circ} \mathrm{C}\right)\left(\mathrm{cm}^{2} / \mathrm{s}\right)$ & $3.4 \times 1$ & $3.2 \times 1$ & $1.2 \times 10^{-8}$ \\
\hline $\left.25^{\circ} \mathrm{C}\right)(\mathrm{c}$ & $1.2 \times 1$ & $5.7 \times 10^{-9}$ & $1.3 \times 10^{-7}$ \\
\hline$D_{\mathrm{E}^{g}}^{g}\left(25^{\circ} \mathrm{C}\right)\left(\mathrm{cm}^{2} / \mathrm{s}\right)$ & $1.2 \times 10^{-8}$ & $5.3 \times 10^{-9}$ & $1.2 \times 10^{-7}$ \\
\hline$E_{\mathrm{A}, \mathrm{PHYS}}^{h}(\mathrm{~kJ} / \mathrm{mol})$ & 66 & 66 & 25 \\
\hline$E_{\mathrm{A}, \mathrm{ION}}{ }^{h}(\mathrm{~kJ} / \mathrm{mol})$ & 32 & 32 & 23 \\
\hline$E_{\mathrm{A}, \mathrm{EX}}{ }^{h}(\mathrm{~kJ} / \mathrm{mol})$ & 34 & 43 & 23 \\
\hline$k_{\mathrm{EX}}{ }^{g}\left(25^{\circ} \mathrm{C}\right)\left(\mathrm{M}^{-1} \mathrm{~s}^{-1}\right)$ & $4.1 \times 10^{6}$ & $2.3 \times 10^{6}$ & $5.1 \times 10^{7}$ \\
\hline$k_{\mathrm{EX}, \mathrm{CORR}^{i}}\left(25^{\circ} \mathrm{C}\right)\left(\mathrm{M}^{-1} \mathrm{~s}^{-1}\right)$ & $2.7 \times 10^{6}$ & $1.6 \times 10^{6}$ & $2.4 \times 10^{7}$ \\
\hline
\end{tabular}

${ }^{a}$ Concentrations of the $\mathrm{Cp}_{2} \mathrm{Co}$ melt are calculated from density measurements and mass: $\rho=1.2 \mathrm{~g} / \mathrm{mL}$ for $\left[\mathrm{Cp}_{2} \mathrm{Co}\right]\left(\mathrm{MePEG}_{350} \mathrm{SO}_{3}\right)$, $1.4 \mathrm{~g} / \mathrm{mL}$ for [FcTMA] $\left(\mathrm{MePEG}_{350} \mathrm{SO}_{3}\right)$, and $1.09 \mathrm{~g} / \mathrm{mL}$ for $\mathrm{MePEG}_{350}$ (as given by Aldrich). ${ }^{b} \delta$ is the redox center-to-center distance calculated from the concentration assuming cubic packing. ${ }^{c}$ From chronoamperometry ${ }^{15}$ of $10 \mathrm{~mol} \% \quad\left[\mathrm{Cp}_{2} \mathrm{Co}\right]\left(\mathrm{MePEG}_{350} \mathrm{SO}_{3}\right)$ in [FcTMA] $\left(\mathrm{MePEG}_{350} \mathrm{SO}_{3}\right)$ or $10 \mathrm{~mol} \%\left[\mathrm{Cp}_{2} \mathrm{Co}\right]\left(\mathrm{MePEG}_{350} \mathrm{SO}_{3}\right)$ in 1.4:1 $\mathrm{mol} / \mathrm{mol} \mathrm{MePEG}_{350}$-plasticized [FcTMA] $\left(\mathrm{MePEG}_{350} \mathrm{SO}_{3}\right)$; each value is the average of three trials. ${ }^{d}$ Calculated from eq 3. ${ }^{e}$ Mole-fractionweighted average of $D_{\mathrm{PHYS}}, D_{\mathrm{CION}}$, and where FcTMA is present, $D_{\text {PHYS,Fe }}=5.5 \times 10^{-9} \mathrm{~cm}^{2} / \mathrm{s}$ at $25{ }^{\circ} \mathrm{C}$. ${ }^{f}$ From microdisk equation. ${ }^{14}$ ${ }^{g}$ Calculated via eq 2. ${ }^{h}$ From slopes of activation plots in Figure 5. ${ }^{i}$ Calculated using Saveant's theory. ${ }^{19}$

electrode reactant and the $D_{\mathrm{APP}}\left(\right.$ and $k_{\mathrm{EX}}$ ) value of the $\left[\mathrm{Cp}_{2} \mathrm{Co}\right]^{+/ 0}$ electron-transfer reaction. In the mixed $\left[\mathrm{Cp}_{2} \mathrm{Co}\right]\left(\mathrm{MePEG}_{350} \mathrm{SO}_{3}\right) /$ $[\mathrm{FcTMA}]\left(\mathrm{MePEG}_{350} \mathrm{SO}_{3}\right)$ melt, the $\mathrm{Co}(\mathrm{III} / \mathrm{II})$ currents are smaller than those in the neat melt by more than the 2-fold concentration dilution, probably owing to a percolation effect partially limiting the rate of $\mathrm{Co}$ (III/II) electron hopping.

$D_{\text {APP }}$ was calculated from the limiting currents of $1 \mathrm{mV} / \mathrm{s}$ cyclic voltammograms using the radial diffusion microdisk equation. ${ }^{14} D_{\text {APP }}$ results at $25^{\circ} \mathrm{C}$ are given in Table 1 and those for other temperatures in Supporting Information Tables S-1, S-2, and S-3. Combining $D_{\text {APP }}$ with $D_{\text {PHYS }}$ (determined as below) using eq 2 gives $D_{\mathrm{E}}$ and $\mathrm{Co}(\mathrm{III} / \mathrm{II})$ electron self-exchange rate constants $\left(k_{\mathrm{EX}}\right)$, given for $25^{\circ} \mathrm{C}$ in Table 1 and for other temperatures in Supporting Information Tables S-1, S-2, and S-3.

The physical diffusion coefficients of $\left[\mathrm{Cp}_{2} \mathrm{Co}\right]^{+}$were measured under conditions where $\mathrm{Co}(\mathrm{III} / \mathrm{II})$ electron hopping is choked off ${ }^{11}$ by diluting it (down to $10 \mathrm{~mol} \%$ ) with the structurally similar host matrixes [FcTMA] $\left(\mathrm{MePEG}_{350} \mathrm{SO}_{3}\right)$ and $\mathrm{MePEG}_{350}$-plasticized [FcTMA] $\left(\mathrm{MePEG}_{350} \mathrm{SO}_{3}\right)$. The lowered mole fraction of $\left[\mathrm{Cp}_{2} \mathrm{Co}\right]\left(\mathrm{MePEG}_{350} \mathrm{SO}_{3}\right)$ is well below the percolation threshold for electron hopping. ${ }^{11}$ Figure 4 shows the cyclic voltammetry of these melt combinations, where the $\left[\mathrm{Cp}_{2} \mathrm{Co}\right]^{+}$reduction and $[\mathrm{FcTMA}]^{+}$oxidation are seen at negative and positive potentials, respectively. Potential step chronoamperometry was done on the $\left[\mathrm{Cp}_{2} \mathrm{Co}\right]^{+}$wave, stepping the potential from the featureless double layer region to beyond the wave's diffusion controlled plateau. Currents were measured at times sufficiently short to attain a linear diffusion geometry, and $D_{\text {PHYS }}$ was obtained from the slopes of Cottrell plots (current vs $\left.t^{-1 / 2}\right) .{ }^{15}$ Background current corrections were simulated by current-time responses for identical potential steps in a $\mathrm{MePEG}_{350}$-plasticized [FcTMA] $\left(\mathrm{MePEG}_{350} \mathrm{SO}_{3}\right)^{16}$ melt (see Supporting Information Figures S-5 and S-6). The results for $D_{\text {PHYS }}$ in the neat and plasticized melts are given in Table 1

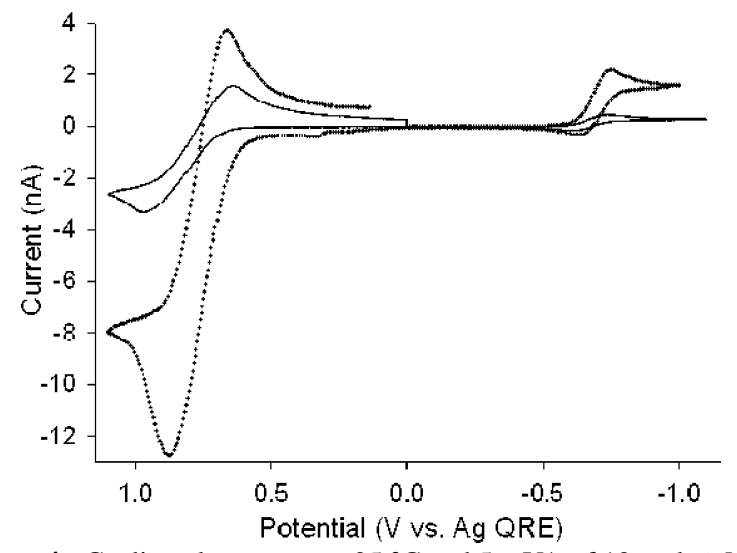

Figure 4. Cyclic voltammetry at $25^{\circ} \mathrm{C}$ and $5 \mathrm{mV} / \mathrm{s}$ of $10 \mathrm{~mol} \%\left[\mathrm{Cp}_{2^{-}}\right.$ $\mathrm{Co}]\left(\mathrm{MePEG}_{350} \mathrm{SO}_{3}\right)$ in [FcTMA] $\left(\mathrm{MePEG}_{350} \mathrm{SO}_{3}\right.$ ) (solid line; the resulting $D_{\text {PHYS }}$ value is $\left.3.9 \times 10^{-10} \mathrm{~cm}^{2} / \mathrm{s}\right)$ and $10 \mathrm{~mol} \%\left[\mathrm{Cp}_{2} \mathrm{Co}\right]\left(\mathrm{MePEG}_{350^{-}}\right.$ $\mathrm{SO}_{3}$ ) in $\mathrm{MePEG}_{350}$-plasticized [FcTMA] $\left(\mathrm{MePEG}_{350} \mathrm{SO}_{3}\right.$ ) (mole ratio 1.4: 1) (dotted line; the resulting $D_{\text {PHYS }}$ value is $1.1 \times 10^{-8} \mathrm{~cm}^{2} / \mathrm{s}$ ).

and Supporting Information Tables S-1 and S-2. $D_{\text {PHYS }}$ and ionic conductivity values were assumed to be the same in the structurally similar $1: 1$ mixed $\left[\mathrm{Cp}_{2} \mathrm{Co}\right]\left(\mathrm{MePEG}_{350^{-}}\right.$ $\left.\mathrm{SO}_{3}\right) /[\mathrm{FcTMA}]\left(\mathrm{MePEG}_{350} \mathrm{SO}_{3}\right)$ and neat $\left[\mathrm{Cp}_{2} \mathrm{Co}\right]\left(\mathrm{MePEG}_{350^{-}}\right.$ $\mathrm{SO}_{3}$ ) melts.

The diffusion coefficients $\left(D_{\mathrm{CION}}\right)$ of the $\left(\mathrm{MePEG}_{350} \mathrm{SO}_{3}{ }^{-}\right)$ counterion were calculated from (ac impedance) measurements of melt ionic conductivities $\left(\sigma_{\mathrm{ION}}\right)$ using the Nernst-Einstein equation $^{17}$

$$
\sigma_{\mathrm{ION}}=F^{2} / R T\left[z_{\mathrm{Co}}^{2} D_{\mathrm{PHYS}} C_{\mathrm{Co}}+z_{\mathrm{CION}}^{2} D_{\mathrm{CION}} C_{\mathrm{CION}}\right]
$$

where $z, D$, and $C$ are the charge, diffusion coefficient, and concentration of the indicated species, respectively, and $D_{\text {PHYS }}$ of the Co complex is measured as above. Table 1 and Supporting Information Tables S-1 and S-2 give the resulting $D_{\mathrm{CION}}$ values. In the mixed melt, the additional diffusing ion, $[\mathrm{FcTMA}]^{+}$, is accounted for by including the term $z^{2} \mathrm{Fe} D_{\mathrm{PHYS}, \mathrm{Fe}} C_{\mathrm{Fe}}$ in eq 3 . $D_{\text {PHYS,Fe }}$ was measured chronoamperometrically (see Supporting Information Figure S-7) in a mixed melt of $8 \mathrm{~mol} \%$ [FcTMA]$\left(\mathrm{MePEG}_{350} \mathrm{SO}_{3}\right)$ in $\left[\mathrm{Cp}_{2} \mathrm{Co}\right]\left(\mathrm{MePEG}_{350} \mathrm{SO}_{3}\right)$, suppressing $\mathrm{Fe}$ (II/III) electron hopping by dilution. Table 1 and Supporting Information Table S-3 give the $D_{\mathrm{CION}}$ results for the $1: 1\left[\mathrm{Cp}_{2-}\right.$ $\mathrm{Co}\left(\mathrm{MePEG}_{350} \mathrm{SO}_{3}\right) /[\mathrm{FcTMA}]\left(\mathrm{MePEG}_{350} \mathrm{SO}_{3}\right)$ mixed melt.

At this point, we consider the possible contributions of ionic or electronic migration to the measured currents. A large transference number of the "supporting ions" (i.e., $t_{\mathrm{CION}}$ ) means that (electrostatic) ionic migration of the $\left[\mathrm{Cp}_{2} \mathrm{Co}\right]^{+}$reactant ion should be minor; ${ }^{18}$ the data in Supporting Information Table $\mathrm{S}-4$ confirm this. Electronic migration occurs when $D_{\mathrm{E}}$ is much larger than the counterion diffusion coefficient (the theory ${ }^{19}$ assumes localized redox sites and freely diffusing counterions). The resulting electric field gradient in the sample accelerates electron hopping and therefore enhances the observed $D_{\mathrm{E}}$ value. In the present case, $D_{\mathrm{E}}$ is not entirely negligible compared to the ion diffusivities, with the latter being assessed as molefraction-weighted diffusion coefficients $\left(D_{\mathrm{I}}=D_{\mathrm{PHYS}} x_{\mathrm{Co}}+\right.$ $D_{\mathrm{CION}} x_{\mathrm{MePEGSO}_{3}}+D_{\mathrm{PHYS}, \mathrm{Fe}} x_{\mathrm{Fe}}$, given in Table 1 and Supporting Information Tables $\mathrm{S}-1, \mathrm{~S}-2$, and $\mathrm{S}-3$, with $D_{\mathrm{I}} / D_{\mathrm{E}}$ ratios in Supporting Information Table S-4 that range from 0.1 to 0.6 ). Saveant's theory ${ }^{19}$ and the $D_{\mathrm{I}} / D_{\mathrm{E}}$ values were applied to correct the experimental $D_{\mathrm{E}}$ and $k_{\mathrm{EX}}$ values; the corrected $k_{\mathrm{EX}, \mathrm{CORR}}$ data are given in Table 1 and Supporting Information Tables S-1, $\mathrm{S}-2$, and S-3. The tables show that the electronic migration correction is relatively small, approximately 2 -fold or less. The effect of possible ion pairing is also relatively minor. ${ }^{20}$ 


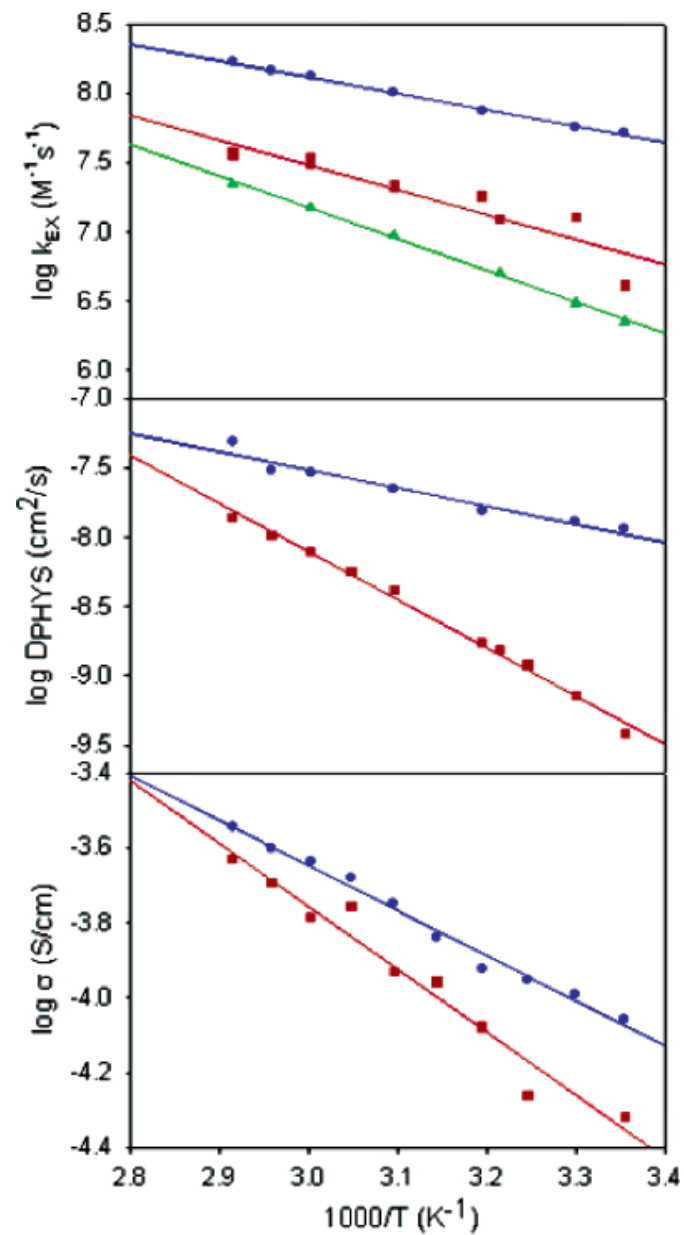

Figure 5. Activation plots of $k_{\mathrm{EX}}\left(\mathrm{M}^{-1} \mathrm{~s}^{-1}\right.$, upper), $D_{\mathrm{PHYS}}\left(\mathrm{cm}^{2} \mathrm{~s}^{-1}\right.$, middle), and $\sigma\left(\mathrm{S} / \mathrm{cm}\right.$, lower) of neat $\left[\mathrm{Cp}_{2} \mathrm{Co}\right]\left(\mathrm{MePEG}_{350} \mathrm{SO}_{3}\right)(\mathbf{\square})$, $\mathrm{MePEG}_{350}$-plasticized $\left[\mathrm{Cp}_{2} \mathrm{Co}\right]\left(\mathrm{MePEG}_{350} \mathrm{SO}_{3}\right)(\bullet)$, and the $1: 1\left[\mathrm{Cp}_{2^{-}}\right.$ $\mathrm{Co}]\left(\mathrm{MePEG}_{350} \mathrm{SO}_{3}\right) /[\mathrm{FcTMA}]\left(\mathrm{MePEG}_{350} \mathrm{SO}_{3}\right)$ mixed melt $(\boldsymbol{\Lambda})$. See Table 1 for activation barrier energies and Supporting Information Tables S-1, S-2, S-3, and S-5 for complete temperature dependent data sets.

The temperature dependencies of $k_{\mathrm{EX}}, D_{\mathrm{PHYS}}$, and $\sigma_{\mathrm{ION}}$ in the three melts (neat, plasticized, and mixed, Supporting Information Tables S-1, S-2, S-3, and S-5) are shown in Figure 5 as activation plots; barrier energies are given in Table 1 . The important result in Table 1 is that $E_{\mathrm{A}, \mathrm{ION}}$ and $E_{\mathrm{A}, \mathrm{EX}}$ are similar and much smaller than $E_{\mathrm{A}, \mathrm{PHYS}}$.

In earlier studies, ${ }^{1 \mathrm{a}, \mathrm{c}, \mathrm{d}, \mathrm{h}, 3 \mathrm{~d}, 4}$ in the context of considering a solvent dynamics model to interpret electron transfers in semisolids, the intercepts of $E_{\mathrm{A}, \mathrm{EX}}$ activation plots such as those in Figure 5 were discussed in terms of their significance for the electron transfers. In the context of the ion atmosphere model, discussed next, we no longer believe that analysis to be appropriate.

Analysis of Electron-Transfer Rates as Ion Atmosphere Controlled. As noted above, an ionic atmosphere relaxation model has been proposed to explain recent ${ }^{4}$ electron-transfer rate constant and physical transport rate results in poly-pyridine Co melts. The essential idea of this model, which originated in a theoretical consideration ${ }^{21}$ of the effect of ion pairing on electron transfers, written in the context of the $\mathrm{Co}(\mathrm{III} / \mathrm{II})$ reaction of $\left[\mathrm{Cp}_{2} \mathrm{Co}\right]^{+/ 0}$, is given by

$$
\begin{aligned}
\mathrm{X}^{-}\left[\mathrm{Cp}_{2} \mathrm{Co}\right]^{+}\left[\mathrm{Cp}_{2} \mathrm{Co}\right]^{0} \underset{k_{-1}}{\stackrel{k_{1}}{\longrightarrow}} \mathrm{X}^{-}\left[\mathrm{Cp}_{2} \mathrm{Co}\right]^{0}\left[\mathrm{Cp}_{2} \mathrm{Co}\right]^{+} \stackrel{k_{2}}{\longrightarrow} \\
{\left[\mathrm{Cp}_{2} \mathrm{Co}\right]^{0}\left[\mathrm{Cp}_{2} \mathrm{Co}\right]^{+} \mathrm{X}^{-} }
\end{aligned}
$$

where ion atmosphere redistribution occurs at rate constant $k_{2}$ following electron transfer at (forward) rate constant $k_{1}$. In the reaction intermediate " $\mathrm{X}^{-}\left[\mathrm{Cp}_{2} \mathrm{Co}\right]^{0}\left[\mathrm{Cp}_{2} \mathrm{Co}\right]^{+}$", the back electron transfer (rate constant $k_{-1}$ ) competes with the ion atmosphere redistribution step. The net electron-transfer rate constant is given by

$$
\frac{1}{k_{\mathrm{EX}}}=\frac{1}{k_{1}}+\frac{k_{-1}}{k_{1} k_{2}}=\frac{1}{k_{1}}+\frac{1}{K_{\mathrm{EQ}} k_{2}}
$$

The ion atmosphere redistribution refers to a physical relocation of charge compensating ions, which can be modeled ${ }^{21}$ as diffusion $\left(D_{\mathrm{CION}}\right.$ or $\left.D_{\mathrm{I}}\right)$ over a distance " $a$ " to relieve the Coulombic imbalance created by the electron transfer:

$$
k_{2}=D_{\mathrm{I}}\left(\frac{\pi}{2 a}\right)^{2}
$$

Clearly, if $k_{1}<k_{2}, k_{\mathrm{EX}}$ should reflect the intrinsic electrontransfer dynamics of the $\left[\mathrm{Cp}_{2} \mathrm{Co}\right]^{+}$couple. On the other hand, if $k_{1}>k_{2}, k_{\mathrm{EX}}$ is instead controlled by the movement of the counterion, and in the limit, one anticipates that the measured (via $D_{\mathrm{APP}}$ ) $k_{\mathrm{EX}}$ value should be proportional to the diffusion coefficient(s) of the surrounding counterions. In the previous cobalt poly-pyridine complex melts, ${ }^{4}$ since the $D_{\text {PHYs }}$ value of the redox complex was much smaller than $D_{\mathrm{CION}}$, only the latter was needed to examine the correlation with $k_{\mathrm{EX}}$. Here, $D_{\mathrm{PHYS}}$ values are not so negligible and may augment the ion atmosphere relaxation rates, so a mole-fraction-weighted ion diffusion coefficient $\left(D_{\mathrm{I}}\right)$ (Table 1$)$ is employed in the Figure 6A $\log -$ $\log$ plots of the $k_{\mathrm{EX}}$ values of the $\left[\mathrm{Cp}_{2} \mathrm{Co}\right]^{+/ 0}$ reaction versus $D_{\text {I. }}$ The plots for the neat $(\square)$, plasticized $(\bigcirc)$, and mixed $(\triangle)$ melts are linear with $\log -\log$ slopes of $1.2,0.9$, and 1.4 , respectively. (For contrast, Figure 6A also shows $\log -\log$ plots of $D_{\text {PHYS }}$ against $k_{\mathrm{EX}}$, according to the previous ${ }^{1,22,23}$ solvent dynamics model; these exhibit less ideal slopes of $0.5,0.9$, and 0.6.) While the $D_{\text {I }}$ plots in Figure $6 \mathrm{~A}$ are consistent with the ion atmosphere relaxation model, even more impressive is the Figure $6 \mathrm{~B}$ comparison with a large body of data for cobalt(II/I) poly-pyridine ${ }^{1 \mathrm{~d}, 4}$ and a recent ruthenium(III/II) tris-bipyridine and bis-bipyridine-bis-cyano complex ${ }^{7}$ melt data. The offset of different data sets from the main body of data may reflect small differences in the term " $a$ " (eq 6) or " $K_{\mathrm{EQ}}$ " (eq 5). The best-fit line shown in Figure 6B has a slope of 1.0.

The activation barrier energies in Table 1 further support the ion atmosphere relaxation model, in that the energy barriers for electron transfer are similar to those for ionic conductivity but (except the most fluid MePEG-plasticized case, vide infra) much smaller than those for $D_{\text {PHYS }}$.

According to the ion atmosphere relaxation model, the net electron-transfer rate is governed by ionic motions, not the intrinsic electron-transfer rate, which predicts that $k_{\mathrm{EX}}$ results are only apparent rate constants and thus should be independent of the particular redox couple employed. This is perhaps the most impressive aspect of Figure 6B, that different complexes (cobaltocenium, Co poly-pyridine, $\mathrm{Ru}$ poly-pyridine) fall into a common framework and exhibit electron-transfer rates in the same $\left(10^{6}-10^{7} \mathrm{M}^{-1} \mathrm{~s}^{-1}\right)$ range. In contrast, in fluid solutions at $25^{\circ} \mathrm{C}$, the electron-transfer rate constant for $\left[\mathrm{Cp}_{2} \mathrm{Co}\right]^{+/ 0}$ is 4 $\times 10^{7} \mathrm{M}^{-1} \mathrm{~s}^{-1},{ }^{24}$ while that for $\left[\mathrm{Co}(\mathrm{bpy})_{3}\right]^{2+/ 1+}$ is a much faster $1 \times 10^{9} \mathrm{M}^{-1} \mathrm{~s}^{-1} \cdot{ }^{25}$ Clearly, the rate constant for the latter couple in the melts has been suppressed more than the $\left[\mathrm{Cp}_{2} \mathrm{Co}\right]^{+/ 0}$ couple.

We establish below an optically induced electron-transfer activation barrier result that predicts a thermal $E_{\mathrm{A}, \mathrm{EX}}$ barrier of 

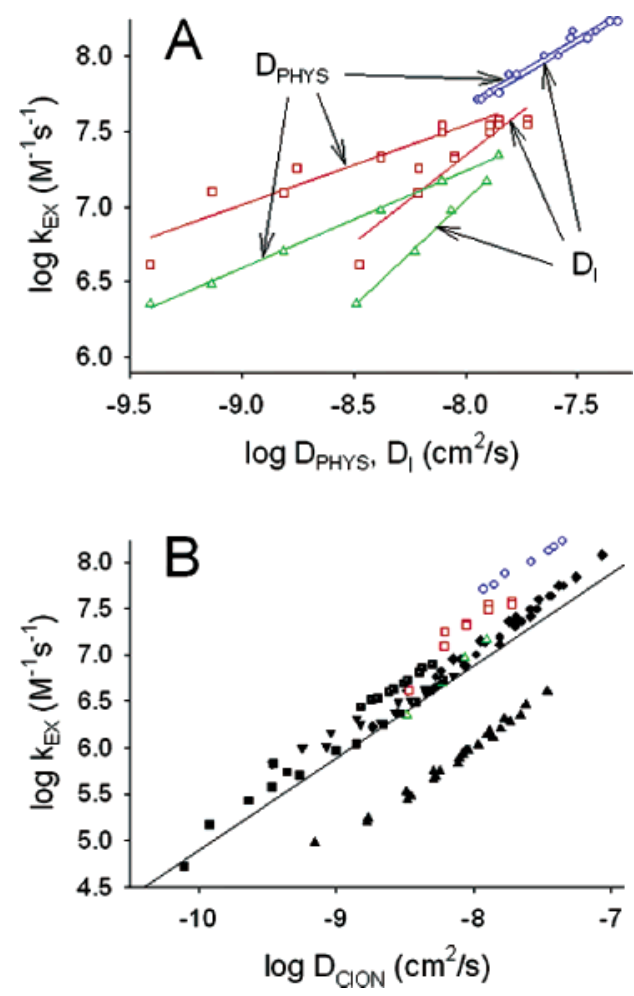

Figure 6. (A) Linear relationship between $k_{\mathrm{EX}}\left(\mathrm{M}^{-1} \mathrm{~s}^{-1}\right)$ for the Co(III/II) electron-transfer reaction vs $D_{\text {PHYS }}\left(\mathrm{cm}^{2} / \mathrm{s}\right)$ and $D_{\mathrm{I}}\left(\mathrm{cm}^{2} / \mathrm{s}\right)$ in neat $\left[\mathrm{Cp}_{2} \mathrm{Co}\right]\left(\mathrm{MePEG}_{350} \mathrm{SO}_{3}\right)(\square), \mathrm{MePEG}_{350}$-plasticized $\left[\mathrm{Cp}_{2} \mathrm{Co}\right]-$ $\left(\mathrm{MePEG}_{350} \mathrm{SO}_{3}\right)(\mathrm{O})$, and the $1: 1 \mathrm{~mol} / \mathrm{mol}\left[\mathrm{Cp}_{2} \mathrm{Co}\right]\left(\mathrm{MePEG}_{350} \mathrm{SO}_{3}\right) /$ [FcTMA] $\left(\mathrm{MePEG}_{350} \mathrm{SO}_{3}\right)$ mixed melt $(\triangle)$, at a range of temperatures $\left(25-70{ }^{\circ} \mathrm{C}\right)$. The slopes for the $D_{\mathrm{PHYS}}$ and $D_{\mathrm{I}}$ correlations are $0.5,0.9$, and 0.6 and $1.2,0.9$, and 1.4 for neat $\left[\mathrm{Cp}_{2} \mathrm{Co}\right]\left(\mathrm{MePEG}_{350} \mathrm{SO}_{3}\right)$, $\mathrm{MePEG}_{350}$-plasticized $\left[\mathrm{Cp}_{2} \mathrm{Co}\right]\left(\mathrm{MePEG}_{350} \mathrm{SO}_{3}\right)$, and the $1: 1\left[\mathrm{Cp}_{2} \mathrm{Co}\right]-$ (MePEG $\left.{ }_{350} \mathrm{SO}_{3}\right) /[\mathrm{FcTMA}]\left(\mathrm{MePEG}_{350} \mathrm{SO}_{3}\right.$ ) mixed melt, respectively. (B) Panel A data combined with previously published data for [Co(phen $\left.)_{3}\right]-$ $\left(\mathrm{MePEG}_{350} \mathrm{SO}_{3}\right)_{2}$ plasticized with $\mathrm{MePEG}_{350}{ }^{4 \mathrm{c}}(\bullet),\left[\mathrm{Co}(\mathrm{phen})_{3}\right]-$ $\left(\mathrm{MePEG}_{350} \mathrm{SO}_{3}\right)_{2}{ }^{4 \mathrm{~b}}(\bullet)$, and $\left[\mathrm{Co}\left(\mathrm{bpy}\left(\mathrm{CO}_{2} \mathrm{MePEG}_{350}\right)_{2}\right)_{3}\right]\left(\mathrm{ClO}_{4}\right)_{2}{ }^{4 \mathrm{a}}(\boldsymbol{\nabla})$, both plasticized with liquid $\mathrm{CO}_{2}$ (over a range of temperatures), [Co$\left.\left(\text { bpy }\left(\mathrm{CO}_{2} \mathrm{MePEG}_{350}\right)_{2}\right)_{3}\right]\left(\mathrm{ClO}_{4}\right)_{2}+x \mathrm{LiClO}_{4}{ }^{1 \mathrm{~d}}(\mathbf{\square})(x=0-1.31)$, [Ru(bpy $\left.\left.\left(\mathrm{CH}_{2} \mathrm{MePEG}_{350}\right)_{2}\right)_{2}\right](\mathrm{CN})_{2}$ plasticized with $\mathrm{CO}_{2}$ (over a range of

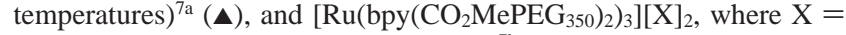
$\mathrm{ClO}_{4}{ }^{-}$or a combination of $\mathrm{ClO}_{4}^{-}$and $\mathrm{I}^{-7 \mathrm{~b}}$ (solid squares with a dot in the middle). The open data symbols in panel $\mathrm{B}$ are the same as those for panel A. The slope of the line shown is 1.0.

$19 \mathrm{~kJ} / \mathrm{mol}$, which is smaller than the results in Table 1 . The difference is consistent with the Table $1 E_{\mathrm{A}, \mathrm{EX}}$ value being not that of the intrinsic electron-transfer reaction but rather that of physical ion motions. It is significant, on the other hand, that, for the MePEG-plasticized $\left[\mathrm{Cp}_{2} \mathrm{Co}\right]\left(\mathrm{MePEG}_{350} \mathrm{SO}_{3}\right)$ melt in Table 1 , the activation barrier energies $\left(E_{\mathrm{A}, \mathrm{ION}}\right.$ and $\left.E_{\mathrm{A}, \mathrm{EX}}\right)$ are not very different from that for physical diffusion $\left(E_{\mathrm{A}, \mathrm{PHYS}}\right)$ and are not much larger than the optically derived $19 \mathrm{~kJ} / \mathrm{mol}$ value. Additionally, the exchange rate constant, $5 \times 10^{7} \mathrm{M}^{-1} \mathrm{~s}^{-1}$, is close to the fluid solution result cited above. From these data, the MePEG-plasticized $\left[\mathrm{Cp}_{2} \mathrm{Co}\right]\left(\mathrm{MePEG}_{350} \mathrm{SO}_{3}\right)$ melt, which is by far (judging by $D_{\text {PHYS }}$ ) the most fluid of the three melts in Table 1, may be close to or at the crossing of the relative values of $k_{1}$ and $k_{2}$ noted above in our discussion of eq 5 . In other words, the results in the MePEG-plasticized $\left[\mathrm{Cp}_{2} \mathrm{Co}\right]-$ $\left(\mathrm{MePEG}_{350} \mathrm{SO}_{3}\right.$ ) melt may come closer than the other melts to reflecting the intrinsic electron-transfer dynamics of the $\left[\mathrm{Cp}_{2} \mathrm{Co}\right]^{+/ 0}$ couple.

Near-IR Spectra of the Mixed-Valent Melt Mixture. We have been previously successful in observing optically induced intermolecular electron transfers in mixed-valent melts that had

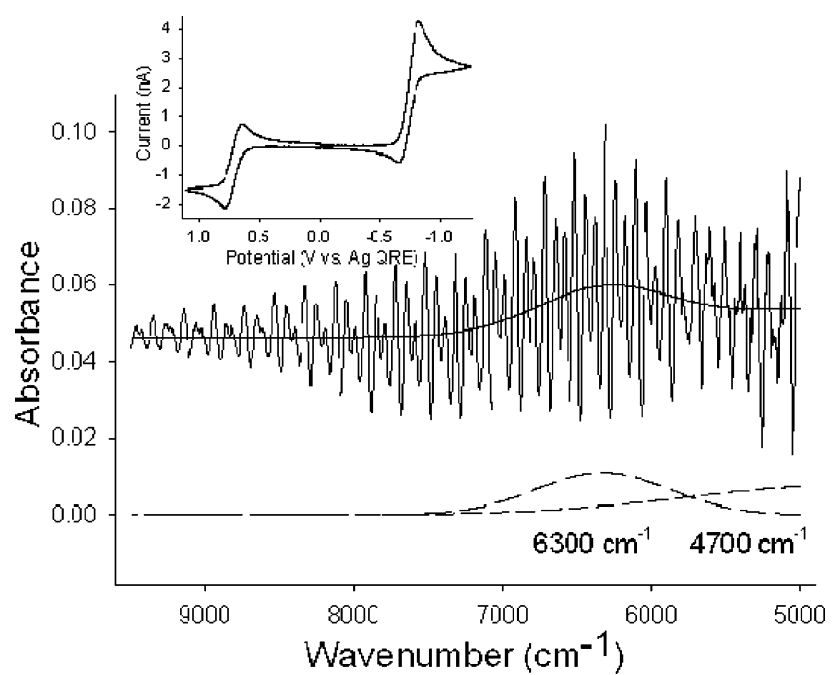

Figure 7. Steady-state NIR peaks from the $1: 1 \mathrm{~mol} / \mathrm{mol}\left[\mathrm{Cp}_{2} \mathrm{Co}\right]-$ $\left(\mathrm{MePEG}_{350} \mathrm{SO}_{3}\right) /[\mathrm{FcTMA}]\left(\mathrm{MePEG}_{350} \mathrm{SO}_{3}\right)$ mixed melt, after $75 \mathrm{~min}$ under a $3 \mathrm{~V}$ bias in a thin layer cell. The large bias is used to overcome the ohmic drop through the thin layer melt, and to allow a faster electrolysis and approach to steady-state concentration profiles in the cell. The raw data, shown with interference fringes, and the fit to the raw data (solid line) are offset above the Gaussian fitted peaks (dashed lines). The inset shows cyclic voltammetry at $1 \mathrm{mV} / \mathrm{s}$ and $25^{\circ} \mathrm{C}$ of the 1:1 $\left[\mathrm{Cp}_{2} \mathrm{Co}\right]\left(\mathrm{MePEG}_{350} \mathrm{SO}_{3}\right) /[\mathrm{FcTMA}]\left(\mathrm{MePEG}_{350} \mathrm{SO}_{3}\right)$ mixed melt at a $\mathrm{Pt}$ microdisk electrode with a radius of $12.4 \mu \mathrm{m}$.

been generated chemically ${ }^{3 \mathrm{c}}$ and by thin layer cell electrolysis. ${ }^{7 \mathrm{a}}$ The latter procedure was employed here to generate a melt containing the $\left[\mathrm{Cp}_{2} \mathrm{Co}\right]^{+/ 0}$ couple.

When the $1: 1\left[\mathrm{Cp}_{2} \mathrm{Co}\right]\left(\mathrm{MePEG}_{350} \mathrm{SO}_{3}\right) /[\mathrm{FcTMA}]\left(\mathrm{MePEG}_{350^{-}}\right.$ $\mathrm{SO}_{3}$ ) melt mixture is confined in an $\sim 50 \mu \mathrm{m}$ layer between transparent, indium tin oxide-coated glass electrodes and an appropriate potential bias is applied, cobaltocenium can be reduced at the cathode to produce a layer of mixed-valent $\left[\mathrm{Cp}_{2} \mathrm{Co}\right]^{+/ 0}$. The currents for the reduction are supported at the anode by ferrocene oxidation, which produces a corresponding mixed-valent $[\text { FcTMA }]^{+2 /+}$ layer next to the anode. The minimum necessary potential is judged by the voltammetric spacing between the two electrode reactions, which is $\sim 1.5 \mathrm{~V}$ as seen in the voltammogram in Figure 7. Figure 7 shows the optical NIR absorbance result of electrolysis at a $3 \mathrm{~V}$ bias; a weak absorbance at $6300 \mathrm{~cm}^{-1}$ and a shoulder at $\sim 4700 \mathrm{~cm}^{-1}$ grow in as mixed-valent layers of $\left[\mathrm{Cp}_{2} \mathrm{Co}\right]^{+/ 0}$ and $[\mathrm{FcTMA}]^{2+/+}$ are produced, reaching an apparent steady state after about 75 min. The time dependencies of the optical absorbance at lower potentials are shown in Supporting Information Figures S-8 and S-9. The spectrum in Figure 7 is overlaid with optical interference fringes caused by the thin layer cell. The lower curve shows the Gaussian fits to the average intensities.

No absorbance peaks are seen in the near-IR spectrum at zero potential bias, when only $\left[\mathrm{Cp}_{2} \mathrm{Co}\right]^{+}$and $[\mathrm{FcTMA}]^{+}$are present. Likewise, $\left[\mathrm{Cp}_{2} \mathrm{Co}\right]^{0}$ and $\left[\mathrm{Cp}_{2} \mathrm{Fe}\right]^{+}$can be eliminated as causes of the band at $6300 \mathrm{~cm}^{-1}$ because dilute solutions of these species have no detectable absorbances in the near-IR wavelength region. ${ }^{26,27}$ Therefore, we infer that the band is caused by electron transfer within one of the two mixed-valent layers produced in the thin layer cell electrolysis. To determine to which mixed-valent couple the $6300 \mathrm{~cm}^{-1}$ energy corresponds, we turn to literature data on dilute solutions of mixed-valent bicobaltocene and biferrocene. Bicobaltocene exhibits an optically induced electron-transfer band from 5880 to $6580 \mathrm{~cm}^{-1}$, depending on the solvent. ${ }^{26}$ The intervalent charge transfer band for biferrocene occurs at lower energies, 5000-5680 $\mathrm{cm}^{-1}{ }^{26}$ 

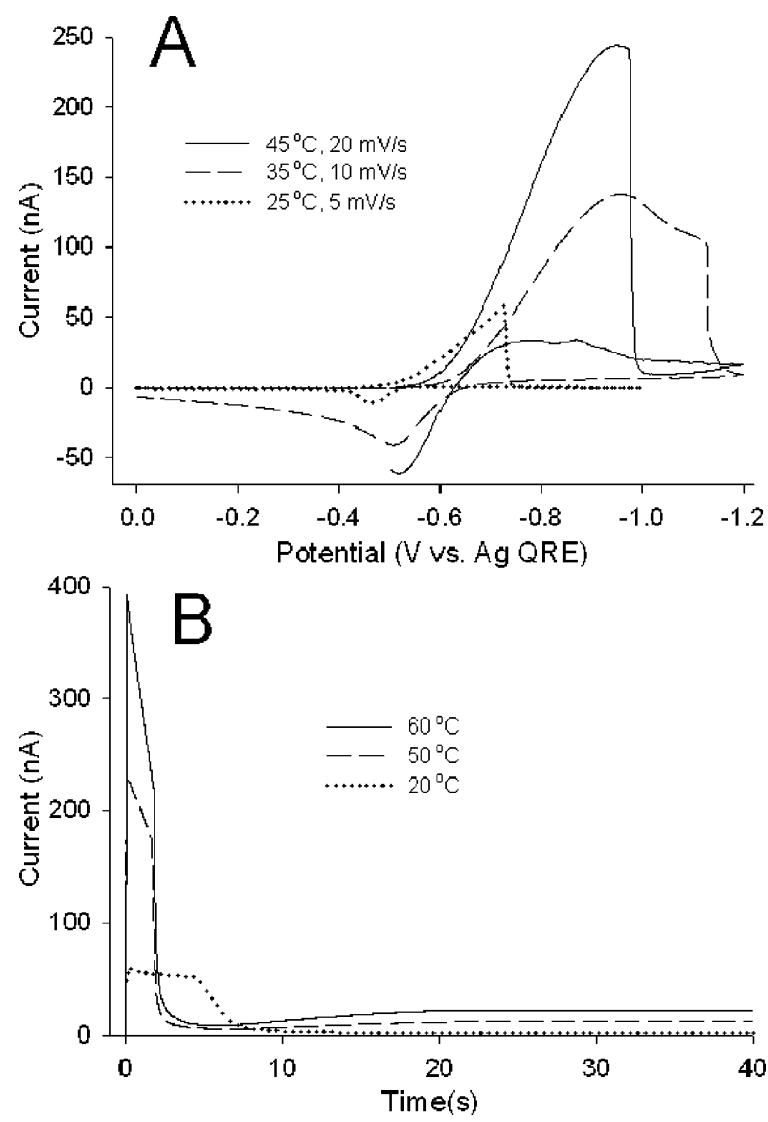

Figure 8. (A) Cyclic voltammetry of neat $\left[\mathrm{Cp}_{2} \mathrm{Co}\right]\left(\mathrm{MePEG}_{350} \mathrm{SO}_{3}\right)$ at various temperatures and scan rates illustrating a nonideal current drop at negative potentials. (B) Potential step chronoamperometry $(\sim 500$ $\mathrm{mV}$, across the $\mathrm{Co}^{\mathrm{III} / \mathrm{II}}$ wave) of neat $\left[\mathrm{Cp}_{2} \mathrm{Co}\right]\left(\mathrm{MePEG}_{350} \mathrm{SO}_{3}\right)$ at various temperatures where a nonideal current drop occurs.

On the basis of these data, the observed $6300 \mathrm{~cm}^{-1}$ band is assigned to the intermolecular $\left[\mathrm{Cp}_{2} \mathrm{Co}\right]^{+/ 0}$ charge-transfer process. The apparent electronic coupling is weak (crude estimate $\left.\epsilon_{\max } \sim 10 \mathrm{M}^{-1} \mathrm{~cm}^{-1}\right)^{28}$ compared to that of mixed-valent bicobaltocene $\left(4500-3500 \mathrm{M}^{-1} \mathrm{~cm}^{-1}\right),{ }^{26}$ probably due to the intermolecular pathway and the $50 \%$ dilution of the $\left[\mathrm{Cp}_{2} \mathrm{Co}\right]^{+/ 0}$ sites.

The most significant aspect of the observed optical electron transfer peak is that its energy, $75 \mathrm{~kJ} / \mathrm{mol}$, according to Hush theory, predicts a thermal electron-transfer barrier energy of 19 $\mathrm{kJ} / \mathrm{mol}^{6}{ }^{6}$ Except for the MePEG-plasticized $\left[\mathrm{Cp}_{2} \mathrm{Co}\right]\left(\mathrm{MePEG}_{350^{-}}\right.$ $\mathrm{SO}_{3}$ ) melt (noted above, $E_{\mathrm{A}, \mathrm{EX}}=23 \mathrm{~kJ} / \mathrm{mol}$ ), this is much smaller than the $D_{\mathrm{APP}}$-derived barrier energies (34 and $43 \mathrm{~kJ} /$ mol) shown in Table 1. That the optically induced electron transfer, which reflects the energetics of the intrinsic electrontransfer process, is smaller than the apparent thermal one is consistent with the preceding analysis; the $D_{\mathrm{APP}}$-based data reflect the barrier energy for ion motions rather than the electrontransfer itself.

Anomalous $\left[\mathrm{Cp}_{2} \mathrm{Co}\right]\left(\mathrm{MePEG}_{350} \mathrm{SO}_{3}\right)$ Voltammetry at Fast Scan Rates. Bond et al. ${ }^{29}$ have reported that reduction of $\left[\mathrm{Cp}_{2}-\right.$ $\mathrm{Co}^{+}$from dilute solutions can lead to precipitation of the neutral product, $\left[\mathrm{Cp}_{2} \mathrm{Co}\right]^{0}$. This apparently also occurs in voltammetry of the neat $\left[\mathrm{Cp}_{2} \mathrm{Co}\right]\left(\mathrm{MePEG}_{350} \mathrm{SO}_{3}\right)$ melt, as seen in Figure 8 by the sudden drop in current during the reductive potential scan in cyclic voltammetry and at longer times in chronoamperometry. The circumstances under which this occurs are limited, however, being confined in cyclic voltammetry to larger (temperature dependent) values of potential scan rate $(>5 \mathrm{mV} / \mathrm{s}$ at $25{ }^{\circ} \mathrm{C}$ and $>20 \mathrm{mV} / \mathrm{s}$ at $45^{\circ} \mathrm{C}$ ).
The results in Figure 8 are consistent with the electrode becoming coated with a partially blocking $\left[\mathrm{Cp}_{2} \mathrm{Co}\right]^{0}$ film. The reductive charge passed before the sudden current drop was estimated from the current-time integrals in experiments such as Figure 8 and converted into equivalent thicknesses of deposited films. The thicknesses, while variable from experiment to experiment (Supporting Information Table S-6), were fractions to several micrometers. These are significant thicknesses when considered as transport-blocking layers. There is generally a reverse peak seen in the voltammetry (Figure 8A), but the charge under it is much less than the forward charge. Either the film is not completely stripped, radial diffusion disperses dissolved film, or the film is continually dissolving and the actual thickness is much less than that estimated in Supporting Information Table S-6. The latter seems to be the most likely, since the currents in Figure 8 do not drop to zero but to small, fairly steady values. If these currents approximate a dissolution rate, conversion of them to thickness/second (Supporting Information Table S-6) shows that it is quite appreciable in comparison to the material reacting prior to the drop in current. Thus, at sufficiently slow potential scan rates, or at higher temperatures, as in Figures $2-4$, the $\left[\mathrm{Cp}_{2} \mathrm{Co}\right]^{0}$ film is either not produced or dissolves too rapidly to hinder diffusional transport.

The data taken at slow scan rates, where blocking is not seen, are considered reliable. (The mismatch between experiment and simulation at lower temperatures in the neat melt, Supporting Information Figure S-1, could reflect a minor degree of film formation.) In the MePEG-plasticized and mixed melts, effects such as Figure 8 were never observed.

Acknowledgment. This research is supported in part by the Department of Energy, Division of Basic Sciences. The authors thank Dr. Stephen W. Feldberg for insightful discussions.

Supporting Information Available: Supplementary information on electrochemical measurements, simulated cyclic voltammetry, Cottrell plots, near-IR spectra, the temperature dependence of $D_{\mathrm{PHYS}}, D_{\mathrm{CION}}, D_{\mathrm{I}}, \sigma, k_{\mathrm{EX}}, k_{\mathrm{EX}, \mathrm{CORR}}$, and migration parameters, and data for reductive cobaltocene film formation. This material is available free of charge via the Internet at http:// pubs.acs.org.

\section{References and Notes}

(1) (a) Dickinson V, E.; Masui, H.; Williams, M. E.; Murray, R. W. J. Phys. Chem. B 1999, 103, 11028. (b) Dickinson V, E.; Williams, M. E. Hendrickson, S. M.; Masui, H.; Murray, R. W. J. Am. Chem. Soc. 1999, 121, 613. (c) Williams, M. E.; Masui, H.; Long, J. W.; Malik, J.; Murray, R. W. J. Am. Chem. Soc. 1997, 119, 1997. (d) Williams, M. E.; Lyons, L. J.; Long, J. W.; Murray, R. M. J. Phys. Chem. B 1997, 101, 7584. (e) Williams, M. E.; Crooker, J. C.; Pyati, R.; Lyons, L. J.; Murray, R. W. J. Am. Chem. Soc. 1997, 119, 10249. (f) Velazquez, C. S.; Hutchison, J. E.; Murray, R. W. J. Am. Chem. Soc. 1993, 115, 7896. (g) Poupart, M. W.; Velazquez, C. S.; Hassett, K.; Porat, Z.; Haas, O.; Terrill, R. H.; Murray, R. W. J. Am. Chem. Soc. 1994, 116, 1165. (h) Kulesza, P. J.; Dickinson V, E.; Williams, M. E.; Hendrickson, S. M.; Malik, M. A.; Miecznikowski, K.; Murray, R. W. J. Phys. Chem. B 2001, 105, 5833. (i) Williams, M. E.; Masui, H.; Murray, R. W. J. Phys. Chem. B 2000, 104, 10699.

(2) (a) Crooker, J. C.; Murray, R. W. J. Phys. Chem. B 2001, 105 8704. (b) Crooker, J. C.; Murray, R. W. Anal. Chem. 2000, 72, 3245

(3) (a) Hatazawa, T.; Terrill, R. H.; Murray, R. W. Anal. Chem. 1996 68, 597. (b) Emmenegger, F.; Williams, M. E.; Murray, R. W. Inorg. Chem. 1997, 36, 3146. (c) Ritchie, J. E.; Murray, R. W. J. Am. Chem. Soc. 2000, 122, 2964. (d) Ritchie, J. E.; Murray, R. W. J. Phys. Chem. B 2001, 105, 11523

(4) (a) Lee, D.; Hutchison, J. C.; Leone, A. M.; DeSimone, J. M.; Murray, R. W. J. Am. Chem. Soc. 2002, 124, 9310. (b) Lee, D.; Harper, A S.; DeSimone, J. M.; Murray, R. W. J. Am. Chem. Soc. 2003, 125, 1096. (c) Harper, A. S.; Lee, D.; Crooker, J. C.; Wang, W.; Williams, M. E.; Murray, R. W. J. Phys. Chem. B 2004, 108, 1866. (d) Leone, A. M.; 
Tibodeau, J. D.; Bull, S. H.; Feldberg, S. W.; Thorp, H. H.; Murray, R. W. J. Am. Chem. Soc. 2003, 125, 6784.

(5) (a) Marcus, R. A.; Sutin, N. Biochim. Biophys. Acta 1985, 811, 265. (b) Marcus, R. A.; Siddarth, P. In Photoprocesses in Transition Metal Complexes, Biosystems, and Other Molecules; Kochanski, E., Ed.; Kluwer Academic Publishers: Dordrecht, The Netherlands, 1992. (c) Sutin, N. Acc. Chem. Res. 1982, 15, 275. (d) Sutin, N. Prog. Inorg. Chem. 1993, 30, 441.

(6) (a) For symmetric, mixed-valence species, $E_{\mathrm{OP}}=4 \Delta G^{*} \mathrm{TH}$, where $E_{\mathrm{OP}}$ is the barrier energy for optically induced electron transfer and $\Delta G^{*} \mathrm{TH}$ is that for thermally induced electron transfer. ${ }^{6 b}$ (b) Hush, N. S. Prog. Inorg. Chem. 1967, 8, 391 .

(7) (a) Ranganathan, S.; Murray, R. W. J. Phys. Chem. B 2004, 108, 19982. (b) Wang, W.; Lee, D.; Leone, A. M.; Murray, R. W. Chem. Phys., in press.

(8) (a) The diameter of $\mathrm{Co}(\mathrm{bpy})_{3}$ is $11.7 \AA$, ${ }^{\mathrm{c}}$ while the diameter of cobaltocenium is $4.12 \AA^{8 b}$ (b) Lukehart, C. M. Fundamental Transition Metal Organometallic Chemistry; Wadsworth, Inc.: Belmont, CA, 1985; p 90.

(9) (a) Dahms, I. J. Phys. Chem. 1968, 72, 362. (b) Ruff, I.; Friedrich, V. J. J. Phys. Chem. 1971, 75, 3297.

(10) $\delta$ is calculated from the melt density on the basis of a cubic lattice model.

(11) Long, J. W.; Velazquez, C. S.; Murray, R. W. J. Phys. Chem. 1996 100,5492

(12) Digisim 3.03; Bioanalytical Systems: Lafayette, IN

(13) (a) Jernigan, J. C.; Chidsey, C. E. D.; Murray, R. W. J. Am. Chem. Soc. 1985, 107, 2824. (b) Maness, K. M.; Terrill, R. H.; Meyer, T. J.; Murray, R. W.; Wightman, R. M. J. Am. Chem. Soc. 1996, 118, 10609. (c) Maness, K. M.; Masui, H.; Wightman, R. M.; Murray, R. W. J. Am. Chem. Soc. 1997, 119, 3987

(14) (a) $I_{\mathrm{SS}}=4 n F r D_{\mathrm{APP}} C{ }^{14 \mathrm{~b}, \mathrm{c}}$ (b) Wightman, R. M. Anal. Chem. 1981, 53, 1125A. (c) Kovach, P. M.; Lowry, C.; Peters, D. G.; Wightman, R. M. J. Electroanal. Chem. 1985, 185, 285.

(15) (a) $i=\left(n F A D^{1 / 2} C\right) /\left(\pi^{1 / 2} t^{1 / 2}\right)$, where $D$ is the diffusion coefficient $D_{\text {PHYs }}$ and the other symbols have the usual meaning. ${ }^{15 b, c}$ (b) Bard, A. J.; Faulkner, L. R. Electrochemical Methods, 2nd ed.; Wiley: New York, 2001 p 163. (c) Cottrell, F. G. Z. Phys. Chem. 1902, 42, 385. (d) The microelectrode radius was determined by ferrocene voltammetry.

(16) Background currents were measured in 5.4:1 $\mathrm{mol} / \mathrm{mol} \mathrm{MePEG}_{350^{-}}$ plasticized [FcTMA] $\left(\mathrm{MePEG}_{350} \mathrm{SO}_{3}\right)$
(17) MacCallum, J. R.; Vincent, C. A. Polymer Electrolyte Reviews; Elsevier Applied Science: Oxford, U.K., 1987; Vol. 1.

(18) (a) $t_{\mathrm{CION}}=z_{\mathrm{CION}}{ }^{2} D_{\mathrm{CION}} C_{\mathrm{CION}} / \Sigma\left(z_{\mathrm{i}}^{2} D_{\mathrm{i}} C_{\mathrm{i}}\right)$. (b) See ref $15 \mathrm{~b}$, pp 65 and 140

(19) Andrieux, C. P.; Saveant, J. M. J. Phys. Chem. 1988, 92, 6761.

(20) The potential effect of ion pairing in the melts, which could depress the apparent $D_{\mathrm{CION}}$ values, was assessed by assuming that $50 \%$ of the $\left[\mathrm{Cp}_{2}-\right.$ $\mathrm{Co}^{+}$complexes are ion paired to polyether-tailed counterions. The calculated $D_{\text {CION,IP }}$ values, given in Supporting Information Table S-4, are increased by $\sim 2-4$-fold. We have no direct evidence for strong contact ion pairing; this is simply a test to illustrate that the effect of $50 \%$ ion pairing is modest.

(21) Marcus, R. A. J. Phys. Chem. B 1998, 102, 10071.

(22) (a) Weaver, M. J. Chem. Rev. 1992, 92, 463. (b) Fawcett, W. R.; Opallo, M. Angew. Chem., Int. Ed. Engl. 1994, 33, 2131. (c) Zusman, L. D. Chem. Phys. 1980, 49, 295. (d) Calef, D. F.; Wolynes, P. G. J. Phys. Chem. 1983, 87, 3387 .

(23) (a) Fawcett, W. R.; Opallo, M. J. Phys. Chem. 1992, 96, 2920. (b) Fawcett, W. R.; Opallo, M. J. Electroanal. Chem. 1993, 349, 273. (c) Fawcett, W. R.; Opallo, M. J. Electroanal. Chem. 1992, 331, 815.

(24) (a) In acetonitrile; ${ }^{24 \mathrm{~b}}$ in dimethyl sulfoxide, $k_{\mathrm{EX}}$ is $2 \times 10^{7} \mathrm{M}^{-1}$ $\mathrm{s}^{-1}$. $^{\mathrm{b}}$ (b) Nielson, R. M.; Golovin, M. N.; McManis, G. E.; Weaver, M J. J. Am. Chem. Soc. 1988, 110, 1745.

(25) (a) This rate constant was obtained in aqueous solution. ${ }^{25 b}$ (b) Sutin, N.; Brunschwig, B. S.; Creutz, C.; Winkler, J. R. Pure Appl. Chem. 1988, $60,1817$.

(26) McManis, G. E.; Nielson, R. M.; Weaver, M. J. Inorg. Chem. 1988 , $27,1827$.

(27) LeVanda, C.; Cowan, D. O.; Leitch, C.; Bechgaard, K. J. Am. Chem. Soc. 1974, 96, 6788 .

(28) The estimate, $\epsilon_{\max } \sim 10 \mathrm{M}^{-1} \mathrm{~cm}^{-1}$, is based on the peak absorbance from Figure 7, a $0.5 \mathrm{M}$ concentration of the absorbing mixed-valent species, and a $25 \mu \mathrm{m}$ path length (one-half of the total thin layer cell thickness) This estimate may be low owing to incomplete development of steadystate concentration profiles in the thin layer cell. Other uncertainties include the implicit assumption that $D_{\mathrm{APP}}$ is the same for the $\left[\mathrm{Cp}_{2} \mathrm{Co}\right]^{+/ 0}$ and $[\text { FcTMA }]^{+2 /+}$ couples.

(29) Cooper, J. B.; Bond, A. M. Anal. Chem. 1993, 65, 2724. 